\title{
Equilibrium
}

Quarterly Journal of Economics and Economic Policy

VOLUME 9 ISSUE 1, 2014

p-ISSN 1689-765X, e-ISSN 2353-3293

www.economic-policy.pl

Nastych M.A (2014), M\&A Cooperative Games, "Equilibrium. Quarterly Journal of Economics and Economic Policy", Volume 9, Issue 1, pp. 119-130, DOI: http://dx.doi.org/10.12775/EQUIL.2014.007

Maria A. Nastych*

University at Saint Petersburg, Saint Petersburg State University, National Re-search University Higher School of Economics, Russian Federation

\section{M\&A Cooperative Games}

JEL Classification: $A 10, A 11, A 12$

Keywords: game theory, coalitions, mergers, acquisitions, $M \& A$

\begin{abstract}
Cooperative game theory instruments application to the corporate finance $M \& A$ research issues provide an ability to extend the field considered and conclusions obtained. The paper presents the $M \& A$ cooperative games modeling and its empirical implementation to analyze the airline strategic alliance as $M \& A$ deal.
\end{abstract}

\section{Introduction}

Cooperative behavior of economic agents is becoming particularly relevant in the context of globalization and information exchange streamlining. Amalgamate entities pursue the goals of strengthening their market position and influence whether it is a mutual cooperation or a hostile takeover. Formation of coalitions between companies can lead both to the establishment of a monopoly power through consolidation, and to an improvement in the quality of products and services and/or a decrease in price by, for example, implementation of partner design and innovation.

\footnotetext{
(C) Copyright Institute of Economic Research \& Polish Economic Society Branch in Toruń Date of submission: April 26, 2013; date of acceptance: December 4, 2013

* Contact: mnastych@eu.spb.ru , European University at Saint Petersburg, Gagarinskaya str., 3, 191187 Saint Petersburg, Russia
} 
Here we present cooperative game theory approach implementation to the M\&A analysis field, which is in corporate finance theory mainstream currently. The first benefit of this method is an ability to research not only mergers and acquisitions, but also preliminary collaboration stage of strategic cooperation, which does not mean the termination of any company. Secondly, it involves an ability to consider more than just two firms as in traditional research practice.

Furthermore, it gives an opportunity to achieve more complex deal scan to facilitate the decision making process. Economic agents' decision whether to merge or not is commonly synergy verifying. If analysts indicate the synergy positiveness, they may conclude the deal expediency. Applying game theory methodology provides us with an opportunity to investigate deal stability, deal fear value and to define companies fear values more precisely.

\section{Mergers and acquisitions cooperative games}

The current practice of analyzing the effectiveness of the strategic cooperation between the two companies does not involve the use of conventional instruments of analysis, due to the contractual basis of the behaviour of the coalition. Meanwhile, due to coalition behaviour affects the companies' fair price value such a methodology becomes necessary, especially when the strategic alliance includes more than two airlines. Analysis of effectiveness of mergers and acquisitions between companies in the corporate finance theory is dedicated to the same issue. It should be mentioned that such verification is to consider only the two coordinating companies.

This work proposes a solution to this problem through the use of cooperative game theory, which will expand both the range of application and the conclusions of analysis of economic integration on the corporate finance theory's results basis.

In international practice, the difference between the terms of merger and acquisition is that these two phenomenons are different stages of cooperation (Whitehurst 2003). However, the difference between these concepts is almost insignificant. Thus, there is no distinction between mergers and acquisitions in the M\&A deal justification process with the instrumental point of view. The choice between mergers and acquisitions is based on institutional prerequisites. The corporate finance theory offers a rationale for cooperative behavior by finding positive synergies from the methodological point of view.

The essential feature here is that the terms "merger" and "acquisition" conform to the Russian law terms. Thus, merger is an integration of two or 
more economic entities which produces a new unified economic unit, while in the case of acquisition all target companies lose their independence and cease to exist and the one conducting the acqiusition gets all the rights and obligations of the liquidated companies.

Thus, we consider the formation of strategic alliances, mergers and acquisitions as a cooperative game with transferable utility. Let us call this class of models as MACG (Mergers and Acquisitions Cooperative Games).

Recall that cooperative game $(\mathrm{I}, \mathrm{v})$ is defined (Печерский 2001) by a finite set of players $I=\{1, \ldots, n\}$ and characteristic function $v: 2^{I} \rightarrow R$, which is defined on the set of all subsets of $\mathrm{I}$ and $\mathrm{v}(0)=0$. The elements of subset $\mathrm{S} \subset \mathrm{I}$ are called coalitions. The values $\mathrm{v}(\mathrm{S})$ are interpreted as gains (benefits, payoffs) of appropriate coalitions $\mathrm{S} \subset \mathrm{I}$.

Efficiency justification process of mergers and acquisitions in the corporate finance theory is reduced to establishing positive synergistic effect that occurs as a result of the growth of capitalization. Capitalization growth is the main companies' objective in accordance with the modern economic theory (Koller 2005). Synergy is an effect of two or more companies' interaction resulting in exceeding their aggregate fair price value above the cumulative amount of their initial values.

As firms seek to maximize their capitalization, characteristic function is defined as the expectation of the coalitions' cost of business. Denote fair value of the coalition $\mathrm{S}$ by $\mathrm{V}_{\mathrm{S}}$ and the cost of its formation by $\mathrm{P}_{\mathrm{S}}$. Then we have:

$$
\mathrm{v}(\mathrm{S})=\mathrm{V}_{\mathrm{S}}-\mathrm{P}_{\mathrm{S}}
$$

Recall that if for any two disjoint coalitions $\mathrm{S}$ and $\mathrm{T}$ the inequality

$$
\mathrm{v}(\mathrm{T})+\mathrm{v}(\mathrm{S}) \leq \mathrm{v}(\mathrm{T} \cup \mathrm{S})
$$

is true, then we conclude that function $\mathrm{v}(\mathrm{S})$ is superadditive. Let $\mathbf{S}_{\mathrm{S}}$ be a synergistic effect for the coalition $\mathrm{S}$. Then,

$$
\mathbf{S}_{\mathrm{S}}=\mathrm{V}_{\mathrm{S}}-\sum_{\mathrm{i} \in \mathrm{S}} \mathrm{V}_{\mathrm{i}}-\mathrm{P}_{\mathrm{S}}
$$

Obviously the synergy is nonnegative if and only if the characteristic function determines the superadditive game. Thus, in terms of cooperative game theory the economic integration is suitable in the case of characteristic function superadditivity.

We assume here that the coalition formation cost is the amount of external services for each of the companies involved in the coalition: 


$$
\mathrm{P}_{\mathrm{S}}=\sum_{\mathrm{i} \in \mathrm{S}} \mathrm{P}_{\mathrm{i}}
$$

This assumption may be explained by the fact that the coalition formation is quite a lengthy process and does not require the simultaneous accession of all participants. Due to this assumption, this parameter is insignificant to determine the feasibility and sustainability of the overall coalition. The point is that a characteristic function, which is the sum of two superadditive ones, is also superadditive. Therefore, we can simplify the characteristic function as:

$$
\mathrm{v}(\mathrm{S})=\mathrm{V}_{\mathrm{S}}
$$

In the most countries the valuation processes, i.e., the fair value estimation, is regulated by law. In the Russian Federation, such activity is regulated by the valuation standards (FSO). Thus, in accordance with the $3 \mathrm{~d} \mathrm{FSO}^{1}$ evaluator is able to choose certain methods of estimation and justify his or her choice under cost-based, comparative and income approaches. We specify the MACG $(I, v)$ characteristic function in accordance with the income approach.

In the current international practice, the first method is not commonly used due to objective reasons. Thus, according to the cost method, the company fair value equals the value of its assets without the debt. But the net book value of a business has no bearing on the case, however great it could be (Валдайцев 2008). For example, the book value depends on the moment of each asset inclusion in balance sheet and on the depreciation method chosen by the company.

Comparative evaluation method is based on the market multiples calculation for a certain company and the industry as a whole. Due to these market multiples, analysts draw conclusions about a company's undervaluation or overvaluation and their potential. The weakness of this methodology using for MACG modeling is the fact that there is a significant specific set of multipliers for each separate industry. Secondly, most of the multipliers can be calculated only for companies whose shares are freely traded. Thirdly, some companies' multiples just must be above or below the industry average, due to specific features of these companies.

Thereby, in this article we consider the determination of the business fair value based on the income approach, or discounted cash flow method (DCF):

${ }^{1}$ Ministry of Economic Development of Russia order by 20.07.2007 N254 Приказ Минэкономразвития России «Об утверждении федерального стандарта оченки «Требования к отчету об оценке (ФСО №3)» от 20.07.2007 №254 


$$
\mathrm{v}(\mathrm{S})=\sum_{\mathrm{t}=1}^{\infty}\left(\mathrm{FCF}_{\mathrm{t}}^{\mathrm{S}}\right) /\left(1+\mathrm{WACC}^{\mathrm{S}}\right)^{\mathrm{t}},
$$

where $\mathrm{FCF}_{\mathrm{t}}^{\mathrm{S}}$ is free cash flow (FCF) of coalition $\mathrm{S}$ in the year $\mathrm{t}$ and $\mathrm{WACC}_{\mathrm{t}}^{\mathrm{S}}$ $=\mathrm{WACC}^{\mathrm{S}}$ is weighted average cost of capital for the coalition $\mathrm{S}$.

According to Gordon's model, a characteristic function can be defined as:

$$
\begin{gathered}
\mathrm{v}(\mathrm{S})=\sum_{\mathrm{t}=1}^{\mathrm{T}}\left(\mathrm{FCF}^{\mathrm{S}}{ }_{\mathrm{t}}\right) /\left(1+\mathrm{WACC}^{\mathrm{S}}\right)^{\mathrm{t}}+ \\
+\left(\mathrm{FCF}^{\mathrm{S}+1}\right) /\left(\mathrm{WACC}^{\mathrm{S}}-\mathrm{g}^{\mathrm{S}}\right)\left(1+\mathrm{WACC}^{\mathrm{S}}\right)^{\mathrm{T}+1},
\end{gathered}
$$

where $\mathrm{T}$ is length of FCF forecasting period and $\mathrm{g}^{\mathrm{S}}$ is terminal FCF growth rate of the coalition $\mathrm{S}$ and $\forall \mathrm{S} \mathrm{g}^{\mathrm{S}}<\mathrm{WACC}^{\mathrm{S}}$.

Let then $\mathrm{R}_{\mathrm{t}}^{\mathrm{S}}$ be operating revenue, $\mathrm{Ex}_{\mathrm{t}}^{\mathrm{S}}$ be operating expenses, $\mathrm{T}_{\mathrm{t}}^{\mathrm{S}}$ be $\mathrm{ab}$ solute value of the deducted tax, $\mathrm{CAPEX}_{\mathrm{t}}^{\mathrm{S}}$ be the amount of capital expenditures and $\mathrm{NI}^{\mathrm{S}}{ }_{\mathrm{t}}$ be net investments in the year $\mathrm{t}$ :

$$
\mathrm{FCFS}_{\mathrm{t}}=\mathrm{RS}_{\mathrm{t}}-\mathrm{Ex}_{\mathrm{t}}-\mathrm{TS}_{\mathrm{t}}-\mathrm{CAPEX}_{\mathrm{t}}+\mathrm{NIS}_{\mathrm{t}}
$$

These indicators should be calculated for each coalition according to the form (strategic alliances, mergers and acquisitions) and the type (horizontal integration, vertical integration and conglomerate) of the companies' cooperative behavior.

The weighted average cost of capital rate in this model is calculated on the basis of the policy of available resources distribution ratio within the coalition and of the tax rate. Tax rate may vary in dependence, for instance, on whether in the coalition the company with the tax benefits right exists or on the country of common coalition residence. WACC is calculated also based on the ratio $\beta^{\mathrm{S}}$ :

$$
\begin{gathered}
\mathrm{WACC}^{\mathrm{S}}=\mathrm{k}_{\mathrm{d}}^{\mathrm{S}}\left(1-\operatorname{tax}^{\mathrm{S}}\right) \mathrm{D}^{\mathrm{S}} /\left(\mathrm{D}^{\mathrm{S}}+\mathrm{E}^{\mathrm{S}}\right)+\mathrm{k}_{\mathrm{e}}^{\mathrm{S}} \mathrm{E}^{\mathrm{S}} /\left(\mathrm{D}^{\mathrm{S}}+\mathrm{E}^{\mathrm{S}}\right) \\
\mathrm{k}_{\mathrm{e}}^{\mathrm{S}}=\mathrm{r}_{\mathrm{f}}+\beta^{\mathrm{S}}\left(\mathrm{r}_{\mathrm{m}}-\mathrm{r}_{\mathrm{f}}\right)
\end{gathered}
$$

Here, $\mathrm{D}^{\mathrm{S}}$ is amount of coalition $\mathrm{S}$ debt, $\mathrm{E}^{\mathrm{S}}$ is its equity, $\operatorname{tax}^{\mathrm{S}}$ is corporate income tax rate, $\mathrm{k}_{\mathrm{d}}^{\mathrm{S}}$ is rate of return on debt, $\mathrm{k}_{\mathrm{e}}^{\mathrm{S}}$ is rate of return on equity, $\mathrm{r}_{\mathrm{m}}$ is market rate of return and $r_{f}$ risk-free rate of return.

The modern literature on the theory of corporate finance, accepted to correct the coefficient $\beta^{S}$ for certain coalition as an average coalition's beta weighted by cost of equity (Moulin, 2003) in accordance with the international global market as a result of the capital market globalization. 


$$
\beta^{\mathrm{S}}=\sum_{\mathrm{i} \in \mathrm{S}}\left(\beta^{\mathrm{i}} \mathrm{E}^{\mathrm{i}}\right) / \sum_{\mathrm{i} \in \mathrm{S}} \mathrm{E}^{\mathrm{i}}
$$

In special cases, there is a possibility to optimize some of these indicators. In such situations, relative formulas will differ in the dependence of form and type of cooperative behavior. For example, in the way of different countries' residents merger a new venture may have an opportunity to choose a country for residence. Obviously, in this case, their choice will be largely justified by the system of corporate taxation in these countries. Considering an acquisition, an indicator of corporate income tax rate will match the relative tax rate of acquirer's country of residence.

There is a difference in the pattern of changes in operating and financial performance between the strategic alliance form of coalition behavior and behavior by the type of M\&A. In the second case it varies by actual changes in balance sheet and all departments and parties association. In the first case we can observe the lack thereof.

Cooperation within the framework of diversification and vertical integration does not allow optimizing the structure of production costs, while horizontal integration does. Structure optimization of such external costs as the cost of marketing and R\&D or the cost of debt service are available for all three types considered. The ability to optimize the structure of fixed costs also exists for all of types of integration. The set of these cost items may include, for example, joint use of warehouse and industrial premises. In the case of vertical integration, it may also include the costs optimization of which is related to the specifics of companies' chain activities constructing. It contains the various stages of processing and maintenance of manufactured product, usually carried out on the basis of several enterprises. Diversification allows reducing the fixed costs associated with providing related products to consumers. Horizontal integration is characterized by the decrease in the fixed costs associated with work with suppliers. For M\&A cooperation it is possible to achieve costs reduction by optimizing the structure of the new company being formed. Namely, it is possible to eliminate the departments' duplication functions, to reduce the number of employees with similar functions.

Using these cost estimates for coalitions, it is possible to calculate their total operating costs with the help of forecasted future volumes of goods and services they provide. In itself, the business integration that occurs as a result of companies' coalition behavior is likely to lead to growth of demand on providing goods and services due to, for example, increase of trust, brand awareness, sales outlets, due to sharing client databases. Diversification and vertical integration facilitate a decline in the risk by reducing the volatility of the companies' revenue stream and improve companies' stability to external economic conditions. 
It is worth noting, however, that the assumption of the company's commitment to maximize the value of the business is not always satisfied in general, as well as the assumption of rationality of players. If we assume the possibility of irrational behavior or non-economic purposes of cooperating companies, the M\&A game model can be extended to the case of the characteristic function with side-payments. Cooperative companies can, for example, pursue the goals of their parent companies, the state, the private individuals. Thus, the benefits derived by the players can be different.

If the assumption of a striving to maximize capitalization is satisfied, the value of the characteristic function reflects the total fair value for each coalition. Then the game solution, that is, the gains allocation among the players, is the fair value of each player separately. Cooperative game theory expects each coalition's players to have their own goals. In other words, each company-participant makes a decision on cooperation on the basis of possible change in its own gain to increase capitalization. Nonetheless, the interpretation of the game solution also depends on the cooperation form.

In the case of strategic alliance, companies remain formally independent economic agents. Thereby the characteristic function is hypothetical while gains allocation does not. The decision to cooperate certainly affects the value of business, changing cash flow and making it impossible to calculate their fair value separately from coalition's partners. Fair value calculation in accordance with standard methodology ignores this fact. So, the definition of gains allocation through the characteristic function value becomes necessary when planning as important financial company's indicators.

In contrast, in the case of M\&A deals the characteristic function is not hypothetical, and the allocation vector often is. Nevertheless, terminating participants' activity as a separate business, coalitions often hold their brands under new one company. Furthermore, mergers and acquisitions can be implemented in the form of equity stakes purchase or equity stakes exchange. Hypothetical property of gains allocation is useful for possible coalition splitting.

Another important interpretation of the allocation vector is a fair acquisition price or fair value of exchangeable shares for the merger. It is usually the most controversial issue in conducting such deals. Thus, the assessment of companies that have undergone or will undergo conversion by merger or acquisition is a key issue of financial and strategic planning. 


\section{Strategic alliance as MACG}

The increasing role of these possible forms of coalition behavior can be observed, for example, in the aviation industry. In order to achieve greater efficiency in the international market, competitive airlines are seeking to increase the number of routes, quality of service, reduce costs, integrating into alliances, concluding interline agreements and agreements on code-sharing. Saturation of the world airlines market leads to the need for consolidation through mergers and acquisitions. Air alliances and airlines groups are gaining importance and scope in the airline business.

In particular, aviation industry is strategically important for Russia. The international market of passenger air transportation has significant potential for Russia due to the geographical position of Russia, business activity growth, increasing role of the international business, social and political relations. The closure of the Russian market by virtue of state share participation and control prevents the active participation of foreign companies in performing domestic scheduled flights on the one hand, and thus cause lethargy in negotiations with Russian airlines. The state of domestic fleet is another factor that prevents involvement of Russian airlines in the international market. Russia's accession to the WTO is leading to significant changes in this industry. Thus, the possible consolidation of Russian and foreign companies analysis, withdrawal of administrative barriers, such as a limit on foreign pilots working in domestic companies, established by the Air Code, begins to play a key role in an effort to achieve economic efficiency of the international aviation industry.

In this paragraph, MACG instruments application is considered relatively to strategic alliance cooperation form. The airline alliance Oneworld will be analyzed by using its operational and financial data provided by Thomson Reuters. Oneworld was founded in 1999, and now it is the third largest global airline alliance. Oneworld MACG model here is observed by 11 out of 12 its current full members. Thus, Malaysia Airlines is excluded from the model due to its recent joining. It was included on February 1st of this year.

According to data provided, we calculated the weighted average cost of capital rate, forecasted the cash flow for the period 2012-2016 and growth rate in the post-forecast period for all 2049 possible coalitions. Cash flow projections for each possible coalition are based on the above considerations about the nature of the transformation of each of the operating and financial components according to the strategic alliance form of cooperation.

To determine the cash flow discount rate using the above formulas, we first calculated the values of $\beta^{i}$ for each airline $i, r_{m}$ and $r_{f}$. The risk-free rate of return was estimated by the 15 years average monthly yield of thirty-years U.S. Treasury bonds. It is equal to $4.11 \%$. The value of the market risk pre- 
mium was calculated by the median of the differences of monthly yields of S\&P 500 and the monthly yields of thirty-years Treasury bonds over 15 years (Koller 2005). It is equal to $6.84 \%$. The value $\beta^{i}$ for each country was derived as the ratio of the covariance of monthly yields of the local index and S\&P 500 to the value of VaR (Damodaran 2004). The indexes we used are NASDAQ 100 for the USA, FTSE 100 for the UK, Hang Seng for Hong Kong, OMX Helsinki for Finland, IBEX 35 for Spain, Nikkei 225 for Japan, MSCI Chile for Chile, DAX for Germany, ASX All Ordinaries for Aastralia, Amman Financial Market All-Share for Jordan and RTS for Russia.

Despite the fact that the presentation of all the values of the characteristic function is not possible, characteristic function values for each of the players and the Shapley vector can be observed from the Table 1 .

Table 2. Initial Oneworld members gains and Shapley value

\begin{tabular}{|l|r|r|}
\hline \multicolumn{1}{|c|}{ Airline } & \multicolumn{1}{c|}{$\mathbf{v ( S )}$} & \multicolumn{1}{c|}{ Shapley value } \\
\hline American Airlines & 97724330,8 & 534938005,7 \\
\hline British Airways & 18385609,8 & 131574913,1 \\
\hline Cathay Pacific & 17048098,2 & 165134362,2 \\
\hline Finnair & 5072378,3 & 86512168,2 \\
\hline Iberia & 8934164,5 & 71651250,9 \\
\hline Japan Airlines & 25306040,7 & 233734019,0 \\
\hline LAN Airlines & 4205062,3 & 71387391,5 \\
\hline Airberlin & 3520668,1 & 58247705,5 \\
\hline Qantas & 10921074,9 & 143216391,7 \\
\hline Royal Jordanian & 306518,3 & 840106,7 \\
\hline S7 & 4031818,6 & 59478640,7 \\
\hline
\end{tabular}

Source: own calculations based Thomson Reuters data provided.

Traditional fair business value estimation does not take into account the effects resulting from the companies' cooperative behavior. The valuation process involves a consideration of the single firm with the expert assessments at one time. Initial fair values and Shapley values for illustrative purposes are presented also in the Figure 1 and Figure 2, respectively. It can be observed that initial values are not just significantly smaller than corresponding components in the allocation vector, but also are not even proportional to. 
Figure 2. Initial fair airlines-members' values $(\$ \mathrm{mln})$

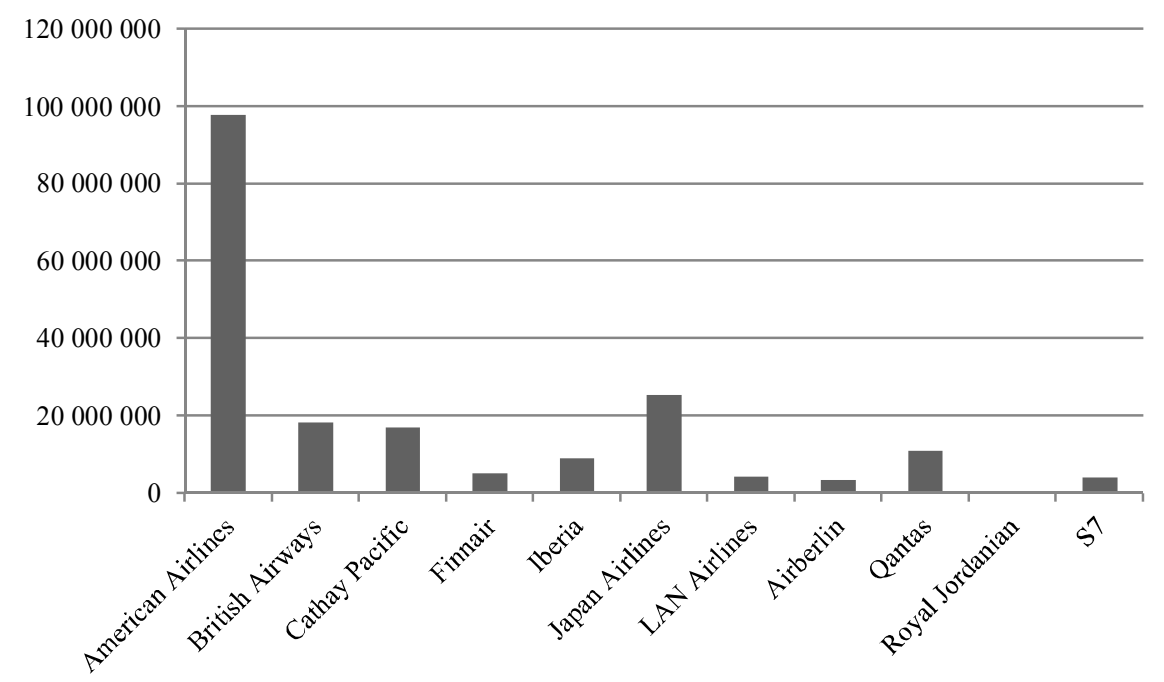

Source: own calculations based Thomson Reuters data provided

Figure 3. Airlines-members' values according to Shapley value $(\$ \mathrm{mln})$

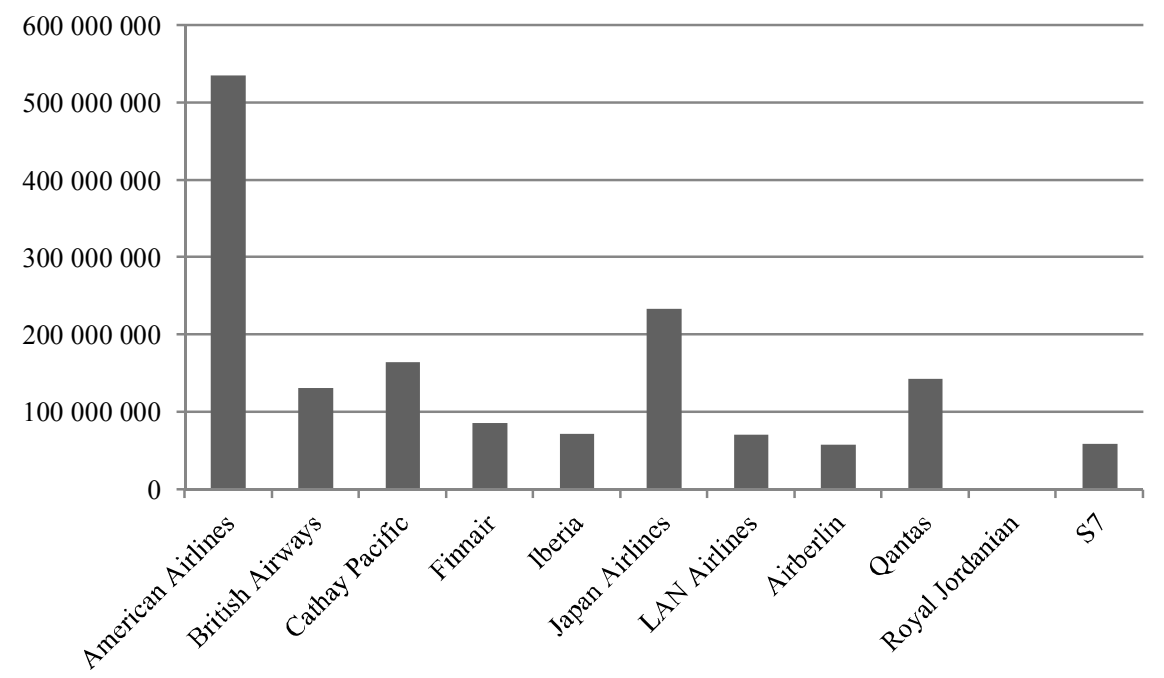

Source: own calculations based Thomson Reuters data provided 
Interpreting the results, it is clear on the one hand that each of the airlines-members gets the surplus from the game. It can be observed from the game superadditivity and from the initial characteristic function values and Shapley values comparison. Thus, for each of them it is beneficial to be the Oneworld alliance' member.

But on the other hand, it can be shown that the Core of this game is empty. By definition, it means that there are some interim coalitions, for which the payoff of each individual participant exceeds its total share in the grand coalition. In other words, there are some groups of airlines, which will tend to exclude some other airlines from the alliance. In these sense, conclusion on the economic stability of Oneworld cannot me made.

It is worth noting still that Malaysia Airlines or other hidden factors could change the unstable situation. Either way, the airlines receive benefits associated with the specifications of the alliance. Airline alliance is a mutually beneficial cooperation which requires compliance with the essential requirements on the one hand, and provides various services of costs reduction, efficiency improvement on the other hand. The airlines enhance competitiveness and strengthen their market positions. MACG model thorough analysis enables to see hidden problems thanks to extensive cooperative game theory methodology.

\section{Conclusions}

In this paper, cooperative game theory instruments implementation to the mergers and acquisitions analysis sphere has been observed. M\&A analysis issues are under corporate finance theory mainstream currently. Combination of corporate finance results and cooperative game theory provide capabilities of extension both the scope of analysis and the results.

First of all, MACG study not only mergers and acquisitions but also preliminary collaboration stage of strategic cooperation. Secondly, it involves an ability to consider unlimited number of economic agents.

Furthermore the large variety of solving concepts with different properties affords the opportunity to receive much broader conclusions about the nature of M\&A deal. Thus, gains allocation can be interpreted as fair business values, taking into account the consequences of economic agent's participation in the coalition. In the case of acquisitions, allocation can be interpreted as a fair price value. Likewise, decision making about the deal in terms of cooperative game theory is based on the fact that the economic integration has a positive synergistic effect in the case of characteristic func- 
tion superadditivity. All the more so, the empty Core in the MACG indicates the economic instability of the coalition concerned.

Thereby, using the concepts of cooperative game theory in relation to M\&A analysis offers important opportunities to interpretation and solving particularly contentious issues. In the last part of the paper, the empirical model for strategic alliance cooperative form was built. MACG analysis features were illustrated on the example of the third largest world airline alliance Oneworld.

\section{References}

Damodaran A. (2010), Applied Corporate Finance, Wiley.

Copeland T., Koller T., Murrin J. (2005), Valuation. Measuring and managing the value of companies, McKinsey\&Company, John Wiley \& Sons, Inc, Hoboken, New Jersey.

Moulin H. (2004), Fair division and collective welfare, The MIT Press, London.

Whitehurst D. (2003), Finance. Fundamentals of Corporate Finance, Vol. 1., The McGraw-Hill Companies, Inc.

Валдайцев С.В. (2012), Оиенка бизнеса и управления стоимостью предприятия, ,Экономика", 1,2 ..

Конюховский П.В., Малова А.С. (2012), Применение методов теории игр в анализе отношений сотрудничества между экономическими субъектами „Вестник Орловского государственного университета. Серия новые гуманитарные исследования", No. 3(23).

Печерский С.Л., Беляева А.А. (2001), Теория игр для экономистов, СПб: Издво Европейского университета в С.-Петербурге. 